The American Journal of Political Science Law and Criminology

(ISSN - 2693-0803)

VOLUME 04 ISSUE 01 Pages: 73-79

SJIF IMPACT FACTOR (2020: 5. 453) (2021: 5 • 952)

OCLC - 1176274523 METADATA IF - 7.659

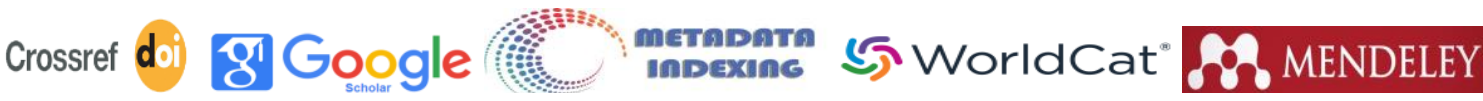

Research Article

\title{
CONCEPT OF VOLUNTARY HEALTH INSURANCE CONTRACT
}

\author{
Submission Date: January 09, 2022, Accepted Date: January 20, 2022, \\ Published Date: January 30, 2022 \\ Crossref doi: https://doi.org/10.37547/tajpslc/Volume04lssue01-12
}

Journal Website: https://theamericanjou rnals.com/index.php/ta jpslc

Copyright: Original content from this work may be used under the terms of the creative commons attributes 4.0 licence.

\section{Boltaev Mansurjon Sotivoldievich}

PhD in Law Associate Professor of the Department of Civil Law, Tashkent State University Law, Uzbekistan

\section{ABSTRACT}

This article states that, unlike compulsory health insurance, voluntary health insurance is based on the freedom of contract, agreement of the parties and voluntary determination of the insured event, insurance conditions, types of medical services provided, sum insured. Therefore, the concept and features of the contract of voluntary medical insurance, the procedure for its conclusion, the importance of determining the subject of the contract are investigated. Also important is the role of the voluntary medical insurance contract in the system of insurance relations, the procedure and conditions for its application in the legislation and the formation of a special legal framework governing these relations. The article analyzes the concept and features of a medical insurance contract.

\section{KEYWORDS}

Medical insurance, voluntary medical insurance, medical care, treatment, insurer, insurer, insured person, insurance premium, insurance premium, sum insured.

\section{INTRODUCTION}

Types and forms of the insurance contract are diverse.

Types and forms of property and personal insurance, voluntary and compulsory insurance, additional insurance, double insurance, co-insurance, mutual insurance and similar types of insurance are distinguished on various grounds, conditions and 
The American Journal of Political Science Law and Criminology

(ISSN - 2693-0803)

VOLUME 04 ISSUE 01 Pages: 73-79

SJIF IMPACT FACTOR (2020: 5. 453) (2021: 5. 952)

OCLC - 1176274523 METADATA IF - 7.659

Crossref

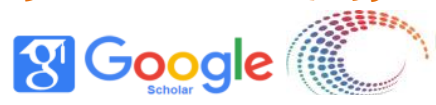
metapata 5 WorldCat

Publisher: The USA Journals

criteria. The legislation does not contain a specific criterion, restriction or requirement regarding the division of insurance into certain types and types. Therefore, there are no strict requirements for the division of insurance into types or their division. Appendix 1 to the Decree of the Cabinet of Ministers of the Republic of Uzbekistan dated November 27, 2002 № 413 "On licensing the insurance activities of insurers and insurance brokers" Appendix 1 "Classifier of insurance activities", although defined, does not contain a strict list of types and types of insurance contracts. The inclusion of a particular type of insurance in a particular network or class of insurance is also very relative and controversial, and depends on the level of thinking and thinking of each specialist. Therefore, the concept of types of insurance, in particular, certain types of insurance contracts and determining their place in the insurance system, is important both from a practical and theoretical point of view.

The concept of a medical insurance contract, including a voluntary medical insurance contract, is not provided for by the current legislation. However, the legislation provides for the division of insurance into voluntary and mandatory types. In particular, Article 914 of the Civil Code of the Republic of Uzbekistan is called "voluntary and compulsory insurance". However, this article does not establish clear rules for voluntary and compulsory insurance and does not provide descriptive aspects of voluntary insurance. It follows from the content of this article that only individuals (individuals and legal entities) and insurance companies can carry out insurance by concluding property and personal insurance contracts, in some cases the obligation to conclude an insurance contract, insurance can be carried out at the expense of the state budget. This abstract expression of this norm provides the basis for its various interpretations, interpretations and applications and does not allow understanding in which cases insurance is voluntary and in which it is mandatory. This approach of the legislator can lead to ambiguity in insurance relations and the emergence of internal conflicts and abuses between insurers and policyholders. This is due to the fact that the division into voluntary and compulsory should include clear boundaries and voluntary insurance to represent the interests of individuals established by law, which are carried out freely and by mutual agreement.

There is no definition of voluntary medical insurance in the legal literature. As noted above, this is due to the fact that insurance payments are different in nature [1]. This is also due to the fact that the current Civil Code ignores other types of insurance, separately defining "property insurance contract" and "personal insurance contract". Commenting on this, Ms. Smirnova said that the legislator refrained from defining a general definition of an insurance contract, based on the following argument: it attaches certain importance. A holistic and unified definition of an insurance contract cannot simultaneously satisfy two requirements (property and personal). Therefore, it is advisable to formulate separate definitions of property and personal insurance [2].

In our opinion, a certain contradiction in the interpretation of this opinion should be noted. The meaning of this point of view is that it is impossible to give a single definition for all types of insurance, but the authors of this point of view do not claim that there can be no definitions dedicated to specific forms and types of insurance. In our opinion, there should be special definitions for certain types of insurance, and they should reflect the specifics of the respective type of insurance and differences from other types of insurance. For example, the Law of the Republic of Uzbekistan "On Compulsory Insurance of Vehicle 
The American Journal of Political Science Law and Criminology (ISSN - 2693-0803)

VOLUME 04 ISSUE 01 Pages: 73-79

SJIF IMPACT FACTOR (2020: 5 - 453) (2021: 5. 952)

OCLC - 1176274523 METADATA IF - 7.659

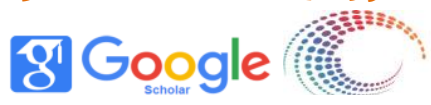

metapata

Owners" [3] defines this agreement (Article 3). In turn, the Law "On Compulsory Insurance of the Employer's Civil Liability" [4] (Article 6) and the Law "On Compulsory Insurance of the Carrier's Civil Liability" [5] (Article 6) determine the relevant contracts.

In a number of CIS countries, including Armenia, Belarus, Kyrgyzstan and the Russian Federation, the Civil Codes do not contain a single definition of an insurance contract, as in the Civil Code of Uzbekistan. On the contrary, the Civil Codes of Georgia and Turkmenistan define the insurance contract, but do not provide for the division of insurance into property and personal [6]. The Civil Code of Azerbaijan defines the general definition of an insurance contract and singles out property and personal insurance as separate objects.

In our opinion, the wrong approach is that the Civil Code does not define an insurance contract, but, on the contrary, defines a property insurance contract (Article 915) and a personal insurance contract (Article 921). Of course, it is advisable to divide the objects of insurance into property and personal. However, instead of the definition of an insurance contract, which is a holistic legal relationship, in our opinion, it is inappropriate to divide the definition into two based on the volume of its two main objects. This, in turn, can lead to various confusions in the understanding and interpretation of the insurance contract, as well as in the legal assessment of insurance contracts. Lawyer T.Umarov argues that property or personal insurance can be voluntary or mandatory, which does not mean that these contracts are not mixed [7]. It turns out that benefits that are both the subject of property and personal insurance can be insured by concluding a single insurance contract. Therefore, it is incorrect to single out separate "property insurance contract" and "personal insurance contract" in the definition of an insurance contract. In our opinion, the Civil Code should define a single "insurance contract" and express it as follows:

Under the terms of the insurance contract, one party (the insurer) undertakes to pay the agreed amount for loss or damage associated with the risk of the insured object, and the other party (the insurer) undertakes to pay the insurance premium (premium), the insurer takes responsibility.

According to V.I.Serebrovsky, an insurance contract is an independent type of civil law contract. This independence is understood as the difference between an insurance contract and other contracts [8]. It is the unit of insurance liability that indicates the need to express the general concept of an insurance contract. After all, an insurance contract is a voluntary document of individuals aimed at establishing insurance relations.

V.P.Kryukov writes that before proceeding to the definition of the legal nature of an insurance contract, it should be noted that its legal essence is not fully and clearly expressed, therefore this issue is the subject of scientific discussions. The difficulty in this regard lies in the fact that the insurance contract does not comply with the norms of existing civil law contracts; it is simultaneously considered as a contract of sale, representation, supply of goods, debt and other similar contracts [9].

In the legal literature, an in-depth analysis of the relationship between the insurance contract and other related contracts is carried out, as a result of which it is concluded that the insurance contract is an independent civil law contract [10]. Therefore, without dwelling on the relationship between insurance liability and related obligations, it should be noted that insurance liability is an integral and independent 
The American Journal of Political Science Law and Criminology (ISSN - 2693-0803)

VOLUME 04 ISSUE 01 Pages: 73-79

SJIF IMPACT FACTOR (2020: 5 - 453) (2021: 5. 952)

OCLC - 1176274523 METADATA IF - 7.659

liability as an institution of civil law, and health insurance - as part of this whole - is divided into two types - mandatory and voluntary.

As mentioned above, a voluntary medical insurance contract is a type of personal insurance. Summarizing this moment, taking into account the role of voluntary medical insurance in the system of insurance obligations, as well as taking into account the civil law features of insurance, we can form the following definition of voluntary medical insurance:

One party (the insurer) under a voluntary health insurance contract provides more services than specified in the compulsory health insurance program provided for medical programs provided by the other party (the insurer) for a fee (insurance premium) and insurance programs agreed with citizens that are part of of this agreement, from time to time or periodically the organization undertakes to finance vape.

The contract for the right to receive the sum insured will belong to the concluded medical institution. This right is imperatively defined in the first part of Article 921 of the Civil Code of the Russian Federation.

According to the general rule of Article 914 of the Civil Code of the Russian Federation, the basis for the formation of insurance relations for voluntary insurance is the contract as a legal instrument for the individual regulation of social relations, on the basis of which the main subjects of the insurance contract: the insurer and the insurer are made.

The study of the contract of voluntary medical insurance allows you to identify the main legal features that determine the features of the contract of voluntary medical insurance in comparison with other types of this contract.
1) The insurance contract is mutual (imposing a bilateral obligation). This agreement describes the existence of concerted actions that represent the mutual will of the participants. The right of one party is an obligation for the other party and vice versa [11].

V.R.Idelson rightly notes that insurance in this matter is a bilateral contract, since it implies the rights and obligations of each of the counterparties [12]. Unlike compulsory health insurance, which is based on the law, the conclusion of an agreement based on the voluntary will of the parties is mandatory for the formation of a legal relationship.

2) Compensation is one of the main features of a voluntary medical insurance contract. The principle of compensation constitutes the economic basis of insurance relations and ensures the performance of the functions that insurance must perform due to the availability of certain funds. This was noted in the 19th century. I.I.Stepanov, who recognized that insurance means predetermined and deliberately accumulated funds in order to avoid adverse consequences, in contrast to the usual accumulation of money for cases when money is needed [13].

Later civilizations: K.A. Grave and L.A. Lunts. Insurance in the broad sense of the word means, first of all, a set of measures for the creation, accumulation of material resources and funds to cover losses in case of unforeseen accidents and accidents, and compensation for losses [14]. Based on the principle of reimbursement, insurance funds were used only in cases where the persons participating in the creation of this fund at their own expense suffered losses.

The current legislation is fully consistent with the principle of reciprocity, expressed by scientists in the 
The American Journal of Political Science Law and Criminology

(ISSN - 2693-0803)

VOLUME 04 ISSUE 01 Pages: 73-79

SJIF IMPACT FACTOR (2020: 5. 453) (2021: 5. 952)

OCLC - 1176274523 METADATA IF - 7.659

Crossref

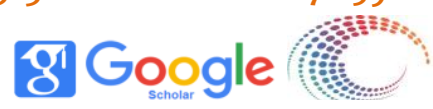

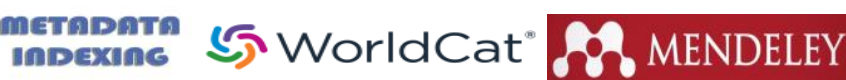

Publisher: The USA Journals

legal literature. A necessary condition for a voluntary medical insurance contract is the payment of insurance premiums (insurance premiums) and insurance rates (Articles 921, 941 of the Civil Code of the Russian Federation), which form a fund to meet the needs of insurers in the event of an insured event. Specified in the contract is evidence of remuneration under this contract.

3) The target orientation of insurance can also be recognized as an independent feature of a voluntary medical insurance contract. Providing a potential need is the purpose of this transaction. That is, the need for public health protection is satisfied by providing insurance coverage to the insured person for the costs associated with his treatment and treatment by the insurance organization.

4) The impossibility to know in advance the events and circumstances that are considered an insured event (coincidence). The norm of Article 929 of the Civil Code also testifies to the concept of an insured event about the accidental nature of insurance. According to this norm, insurance is an event that is insured upon the occurrence of an insured event. In this case, the description of the event must be determined by agreement of the parties.

5) The risky nature of the insurance contract is a decisive condition for insurance [15]. The validity of the insurance contract [16] depends on the realization of the insurable interest of the insurer, and not on the payment of the insurance premium by the insured. Thus, the limit of liability of the insurer is an important condition of the insurance contract and at the same time is the subject of agreement between the parties, which is understood from Article 929 of the Civil Code of the Russian Federation.
The contract of voluntary medical insurance comes into force from the moment of payment of the insurance premium or the first installment (Part one of Article 947 of the Civil Code of the Russian Federation). This is the basis for scientists to include this type of civil law contract in the list of real contracts [17]. However, it should be noted that this rule, provided for by law, is dispositive in nature. If the parties provide for the entry into force of the agreement from the moment an agreement is reached, such an agreement should be recognized as a consensual agreement. In this sense, an insurance contract can be interpreted as a real and consensual contract based on the method of structure and agreement of the parties [18]. In our opinion, a voluntary medical insurance contract can also be real and consensual by agreement of the parties. If the parties have not concluded in the contract a rule on the date of entry into force of the agreement by mutual agreement, the provisions of part one of Article 947 of the Civil Code of the Russian Federation shall apply until the day the agreement enters into force.

The contract of voluntary medical insurance is a conditional contract [19]. The insured has the right to demand compensation for losses (payment of the sum insured) from the insurer only from the moment of occurrence of the insured event. An insured event is the nature of a conditional contract, i.e. a condition and a situation under which it is not known whether an insured event will occur or not (Article 104 of the Civil Code).

As a rule, an insurance contract belongs to the group of causal contracts and depends on the basis for its conclusion. This is due to the fact that in insurance, more than in any other contract, it is necessary to adhere to the consistency between the main (causal) basis and the legal relationship itself. Compliance with the compensatory nature of the obligation, preventing 
The American Journal of Political Science Law and Criminology (ISSN - 2693-0803)

VOLUME 04 ISSUE 01 Pages: 73-79

SJIF IMPACT FACTOR (2020: 5. 453) (2021: 5 • 952)

OCLC - 1176274523 METADATA IF - 7.659

Crossref do

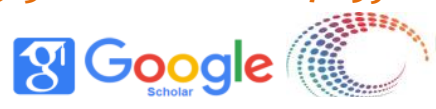

metดDตTล

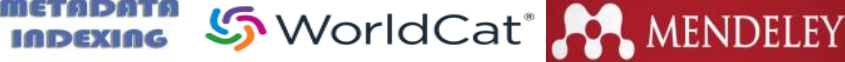

Publisher: The USA Journals

the receipt of unreasonable profits is one of the important conditions for the validity of insurance legal relations.

An insurance contract is always concluded for a fixed period. Due to the direct relationship between the term of the contract and the cost of insurance (Article 929 of the Civil Code of the Russian Federation), the legislator refers the term of the contract to the essential terms of the insurance contract. The issue of the possibility of concluding an insurance contract is raised in response to a written request from the insured and ends with the conclusion of an appropriate contract and the conclusion of an insurance declaration on a fair basis [20].

In our opinion, a voluntary medical insurance contract is a contract that provides for payment for all services provided for in the contract for the provision of medical care to the insured person. The sum insured is reimbursed by the insurer at the expense of the insurance premium or premiums paid by the insured person in the event of an insured event - deterioration in the health of the insured person or the need to provide him with medical care. In this regard, the contract of voluntary medical insurance as a separate independent type of insurance has its place in the protection of public health.

\section{REFERENCES}

1. Smirnova M.B. Insurance Law: Textbook. Yustitsinform. 2007.

2. Smirnova M.B. Insurance Law: Textbook. Yustitsinform. 2007: Civil Code. Book Five: Obligations: A Project Highly Established by the Drafting Commission for the Compilation of the Civil Code. With explanations. 1899. P. 17.

3. Collection of Legislation of the Republic of Uzbekistan, 2008, №. 17, Art. 128.
4. Collection of legislation of the Republic of Uzbekistan, 2009, No. 16, art. 197.

5. Collection of legislation of the Republic of Uzbekistan, 2015, No. 21, Art. 268.

6. Braginsky M. I. Insurance contract. M., 2000. -P.74.

7. Review of the Civil Code of the Republic of Uzbekistan. Volume 3 https://www.osce.org/uz/uzbekistan/106233.

8. Serebrovsky V. I. The concept of an insurance contract in Soviet law // Law and Life. 1926.

9. Kryukov V.P. Insurance law (essays) (according to the edition of 1925). - M.: 1992. - P. 5.

10. Abramov V.Yu. Insurance: theory and practice. M.: Wolters Kluver, 2006. - P. 76.

11. Shiminova M.Ya. Fundamentals of insurance law in Russia. M., 1993. - P. 90.

12. Idelson V.R. Insurance law. Lectures delivered by Rev. V. R. Idelson at the St. Petersburg Polytechnic Institute at the economic department, insurance subdepartment in 1907. M., 1992. - P. 21.

13. Stepanov I. Experience in the theory of the insurance contract. Kazan, 1875. - P. 22.

14. Grave K. A., Lunts L. A. Insurance. M., 1960. - P. 5.

15. Grave K. A., Lunts L. A. Insurance. M., 1960. - P. 55; Ioffe O. S. Law of Obligations. - P. 735; Civil Law: Proc. / Ed. A.P. Sergeev and Yu. K. Tolstoy. Part 2. M., 1997. - P. 504.; Igbayeva G. Civil law characteristics of the insurance contract // Arbitration and civil process, 2007 No. 9.

16. Garaeva, A. D. Aleatory transactions: concept, signs, classification / A. D. Garaeva. - Text: direct // Young scientist. - 2021. - No. 3 (345). - P. 170-173. URL: https://moluch.ru/archive/345/77795/ (date of access: 05/05/2021).

17. Smirnova M. B. Insurance Law: Textbook. Yustitsinform. 2007.

18. Belykh V.S., Krivosheev I., B. Insurance law. - M.: 2003. - P. 16. 
The American Journal of Political Science Law and Criminology

(ISSN - 2693-0803)

VOLUME 04 ISSUE 01 Pages: 73-79

SJIF IMPACT FACTOR (2020: 5. 453) (2021: 5. 952)

OCLC-1176274523 METADATA IF -7.659

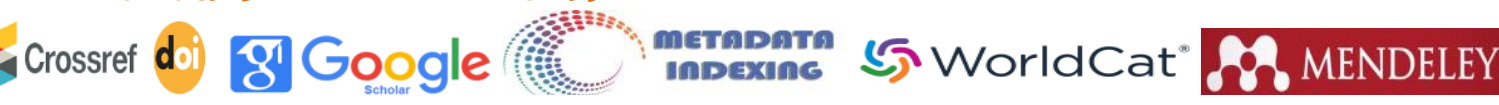

19. Rakhmonkulov H. Agreements. Toolkit. - T .: TDUI. 2009. - P. 47.

20. Gerasimenko L.V. The concept and features of the contract of voluntary medical insurance // Society and law. 2010. No. 2 (29). - P. 84 